\title{
ANATOMY OF PLACE-MAKING IN THE CONTEXT OF THE COMMUNICATION PROCESSES: A STORY OF ONE COMMUNITY AND ONE SQUARE IN A POST-SOCIALIST CITY
}

\author{
Jacek Kotus, Tomasz Sowada, Michaє Rzeszewski, Patrycja Mańkowska \\ Institute of Socio-Economic Geography and Spatial Management, Adam Mickiewicz University, Poznań, \\ Poland
}

Manuscript received: January 19, 2019

Revised version: March 11, 2019

\begin{abstract}
Kotus J., Sowada T., Rzeszewski M., MaŃKOwSKa P., 2019. Anatomy of place-making in the context of the communication processes: A story of one community and one square in a post-socialist city. Quaestiones Geographicae 38(2), Bogucki Wydawnictwo Naukowe, Poznań, pp. 51-66. 7 figs.

ABSTRACT: The article presents a discussion on the anatomy of place-making within the framework of the communication processes against the background of social order in a post-socialist city. The main aim of the text is to look at the social mechanisms of place-making processes "under the microscope". The place-making activities are very often associated with planning and urban design. However, behind that planning veil is the social world of urban neighbourhood communities. In the article we propose, the social communication and participation processes are among the key factors responsible for creating urban spaces. We are presenting a place-making case study, using the example of Asnyk Square in Poznań. In this context, we are analysing social attitudes and social communication, which took place in the course of the place-making processes and influenced urban planning activities. The discussed case is complicated and provides no easy solutions.
\end{abstract}

KEY WORDS: place-making, communication processes, citizen's participation, post-socialist city

Corresponding author: Jacek Kotus, Institute of Socio-Economic Geography and Spatial Management, Adam Mickiewicz University, Poznań, ul. B. Krygowskiego 10, 61-680 Poznań, Poland, e-mail: tatra@amu.edu.pl

\section{Introduction}

Small social groups and communities hold an enormous potential for change. They are referred to as "units of transformation, a bridge between individual existence and the larger community and a source of common belonging" (Block 2009: 95). Neighbourhood becomes the primary small, urban social group. That is probably the reason why neighbourhood life in a large city has been fascinating researchers for years. The literature on the subject is full of theoretical and empirical works which explore the problems of the organisation and life of neighbourhood communities in the city (Jackobs 1961; Downs 1981; Forrest 2000; Galster 2001; Low 2004; Middleton, Murie, Groves 2005; Novy 2011).

The perspective of place-making analysis that interests us is the approach which focuses on the communication processes which occur in connection with the transformations of urban spatial micro-worlds. We are inspired by the assumptions pointing to the role of social communication in creating spaces (Adams 2005, 2009, 2017; Jansson, Falkheimer 2006). According to Jansson and Falkheimer (2006: 7), "the linkage between 
geography and communication lies in the fact that all forms of communication occur in space, and that all spaces are produced through representation, which occurs by means of communication". With reference to these words, we are trying to present the trajectory of communication processes which accompanied the place-making process in a Polish post-socialist city. Do citizens' attitudes to the redevelopment of urban places really depend on whether they are attached to these places or not, or whether they are able to discuss reconstructions or not?

For that purpose, we decided to take a closer look at the mechanisms which accompanied the transformation of one of Poznan neighbourhoods. The main aim of our study was to establish the anatomy of place-making processes in the context of communicational actions. Of course, our perspective, which is a post-socialist social order in the city, is also important. We will attempt to provide answers to the following research questions:

1. How is the communication background of place-making processes created, from the post-socialist city perspective?

2. What kind of social communication accompanies place-making processes from the citizens' point of view?

We may suppose that the psychological mechanisms in the local communities of San Francisco, Poznań, Liverpool, Johannesburg or Hanoi will be the same, just like the psycho-cognitive processes in humans. Regardless of the geographical longitude and latitude, every member of a local community may feel reluctant towards changes on their territory (the immediate neighbourhood), which have not been discussed with them before. On top of this, even if the changes have been discussed, they provoke quite natural resistance of the social matter (Saint, Flavell, Fox 2009; Devine-Wright (ed.) 2015). After all, who likes changes in life, especially if they affect our immediate environment? However, when discussing the mechanisms of change, we should remember that these common psychological schemata occur in various social orders as well as in various cultures - communication systems (Dear 1992; Wiliams 2000; Schirato, Yell 2000; Miller, Das, Chakravarthy 2011; Gu Hongyan 2016). Hence, place-making in different cities around the world may show similarities, but it can or even should also show differences (in the causes, course and/ or effects), resulting from the fact that it is set in different social orders and, consequently, different narratives of life. In other words, the communication framework in a given culture can affect the formation of ordinary places. We do hope that the discussion inspired by these questions will cause some reaction among the readers and encourage them to think more deeply about both the universality and limitations of place-making ideas. We think that our case-study is interesting because of:

- its setting in the post-socialist realities of urban space,

- the possibility of following the whole social process of constructing an ordinary place in the space,

- the temporal dimension (which is even more interesting). We were able to observe various stages of this matter in great detail, while not being constrained with the problems involved in a post factum analysis.

\section{Theoretical background}

\section{Social attitudes towards place-making on the neighbourhood level}

We are advocates of the thesis that urban life comes down to the life of local micro-worlds. Neither the inhabitants of the enormous city of Calcutta, nor of the cosy Italian town of Siena, nor Poznań, a Polish city which is our research area, live in the city as a whole. Their lives take place in socio-spatial micro-worlds, and the neighbourhood micro-world is constitutive of a good life for a city inhabitant. Hence, the "battle for urban space", which we believe to be of key importance, happens at the level of local interactions (Martin 2003). In our opinion, this local character comes down to grass-roots actions, in which the inhabitants of certain areas do not act to carry out macro-structural transformations in the city (bottom-up), but to introduce changes in the local environment, which they are really interested in (Walljasper 2007; Anguelowski 2013). Warrens' community classification (1975), Wellman and Leighton's types of communities changing in time (1979), categories of gated communities distinguished by Blakely and Snyder (1997) or 
Grant and Mittelsteadt (2004) are among the many milestones in the narrative of neighbourhood life in the city. Currently, one of the globally held debates on local communities is the one concerning place-making (Lepofsky, Fraser 2003; Friedmann 2010; Anguelowski 2013). The debate is held from the perspective of the spatial effects of place-making, as well as the social causes, the course and effects of the planning activities. In our work, we would like to take a closer look at the anatomy of such social attitudes accompanying the process of place-making from the point of view of a very local, even neighbourhood-based trajectory of change.

Neighbourhood life, and neighbourhood life in a large city in particular, is the source of various, often conflicting attitudes. In our opinion, the expression "social attitudes" is a key one. The functioning of a neighbourhood community in a large city immanently involves expressive attitudes due to the close, local and territorial character of the neighbourhood. These tensions include those resulting from the relationships between the neighbourhood community and the surroundings, as well as those within the community itself. Trying to describe the specificity of the former, Harvey (1996) indicated that a common phenomenon is the closing up of the people living in one area in order to prevent the invasion of socially unaccepted groups. If we add the activity of city authorities and city visitors, the participation of developers and other external entities in the city, it turns out that there are many exogenous factors causing social tensions in neighbourhood societies (Clark, Kearns et al. 2016; Patterson 2016). When we complete this picture of potential tensions in neighbourhoods with internal differences - ethnic (Glikman, Semyonov 2012; Hanhörster, Weck 2016), social (Wu, Feng Hou et al. 2011) and economic (Owens 2012), potential conflicts become practically inevitable (Buitrago 2013). Some of the tensions and conflicts are destructive to urban social structures. In some cases, however, these tensions should be treated as developmental and structure-creative (Miessen 2011). Publications concerning social participation and collaborative actions are dominated by a discussion about avoiding, anticipating and defusing conflict situations (Moote et al. 1997; Reed 2008). However, there are also works which present civil disobedience as either a creative state with social tensions being a motor of socio-economic development (Miessen 2011; Pløger 2004), or like in the scientific discourse regarding the NIMBY syndrome, as something ordinary and commonplace (McClymont 2011).

\section{A post-socialist perspective as one of many}

When joining the discussion about social attitudes towards ordinary place-making, it is worth remembering that the social nature of people does not exist in isolation. On the one hand, this social human nature (see: place attachment theory) may provoke similar reactions in various cities around the world (Anguelovski 2003). On the other hand, however, cultural differences have an influence on the behaviours, social communications and attitudes of the world cities' inhabitants (Oakes, Price 2008). Both, individual behaviours and local social activity are often set in specific social orders, which have been developing for centuries and have gone through many rapid historical turns. We believe that the analysis of place-making activity must involve "exploring indigenous ontologies" (Larsen, Johnson 2016), and in that context - social or even communicational mechanism. In our case, it means referring to a post-socialist city as an interpretational area (Andrusz, Harloe et al. 1996; Kotus 2006; Tsenkova, Nedović-Budić 2006; Hirt, Ferenčuhová et al. 2017). The reader may of course immediately question the existence of a "post-socialist city reality". Such thinking is highly probable if the reader has not been familiar with such a city before. We believe that not only does a post-socialist city reality exist, but it is also internally diversified if we compare cities in different Central and East European countries. We are talking about cities in countries like Poland, the Czech Republic, Lithuania, Romania, Bulgaria or Albania, which have been following the path of a more or less democratic social order for 25 years. On the one hand, the societies of these cities and countries often belong to economic, political and social structures deriving from Western cultures (for example, participation in social activity, communication rituals, legitimisation of power). On the other hand, they bear a very strong imprint of Soviet Russia. The countries listed above are continually developing European democracies, and the mechanisms which were determining urban development in this part of Europe for at least 50 
years, stigmatised their spatial structure, as well as the mentality, lifestyles, views and approaches of these cities' residents, social interaction and patterns of social communication. For the last quarter of the century, the cities of post-socialist countries have undergone accumulated processes of socio-spatial structure transformation. The processes, which in the West European countries were going on for many decades, took only slightly over twenty years and have not finished yet in post-socialist Europe. Similarly, the citizen democracy in this part of Europe is still very fragile and sensitive, including the forms of communication of the authorities (also city authorities) with the citizens and the other way round. The development of civil liberties is certainly burdened by the fact that before 1989 the citizens of Polish cities could either agree to the authorities' ideas (local and party-dependent at the same time) and praise them, or remain silent. Expressing opinions which were different from those accepted by the authorities was punished with imprisonment and declaring a person as "an enemy of the people". The authorities (also the city ones) had to be listened to and obeyed. Those who disagreed could only stay quiet or protest. As a result, the processes of communication between the authorities and the inhabitants of Polish cities are often marked with rebellion, resistance and rejection of the authorities' actions.

Let us not forget here about regional historical changes. In the case of Poznan - it is a history of social protests dating back to the second partition of Poland in 1793. From that time until 1989, Poznań was subjected to strong social, political and economic influences of different occupiers for nearly two centuries. Poznań could function as a fully independent city only between 1918 and 1945, and later, after the Round Table Talks in Poland and the fall of the Berlin Wall in 1989. "Standing up against authorities" became something natural for a Pole and a Poznan resident; legitimisation of authority is something rare and highly unnatural. It can be said that protest and objection is something the inhabitants of this region have inherited from the previous generations (Davis 1981).

Hence, when you are reading the next empirical subchapters, wondering about the behaviours of city authorities and the inhabitants of the Asnyk Square area, bear in mind this background, which is not only a socio-historical veil, but also a strongly internalised system of behaviour patterns and social norms.

\section{Methods of research}

We are of the opinion that individual case studies allow us to explain more accurately and profoundly the mechanisms of human actions in the context that interests us - behaviours in space and with reference to space. Hence, in the course of the study, we used methods which enabled us to look at the case study from a socio-ethnographic point of view or, in more descriptive words, from the perspective of local actions and inhabitants' opinions:

- a social action trajectory - identification of the communication processes of place-making,

- a study of collective opinions - a survey identification of the declarative attitudes,

- selected in-depth interviews (IDI) - identification of more-grounded attitudes.

As regards the social action trajectory, we are building a specific axis of time and events which took place during the public discussions about Asnyk Square, about taking successive decisions and about the turns of action when those decisions were being announced by the authorities. We suspect that creating such a trajectory will enable the readers to notice the similarities and differences between actions in similar cases and it will show the stages and mechanisms of communication processes. The axis will be of course supplemented with our comments and a qualitative description of individual attitudes during the place-making process in Asnyk Square, in order to establish the actual social attitudes that emerged during its transformation.

The study of collective opinions was conducted by means of a quantitative survey carried out among the local community of the area adjacent to the square. We used the convenience (non-probability) sampling method which allowed us to reach the available inhabitants of the Jeżyce neighbourhood. We were able to collect 102 questionnaires, with nearly half of them returned by permanent residents of the Jeżyce area who had not changed their place of residence for over 10 years. The respondents varied as regards their age, gender, education and length of stay at 
the present place of residence. $61 \%$ of them were female and $39 \%$ were male. The most numerous age groups consisted of people aged 30-39 (30\%) and $25-29(22 \%)$. The least numerous were the extreme age groups, including persons aged 70 and above (5\%) and 18-24 (7\%). The respondents' level of education was higher $(61 \%)$, secondary $(30 \%)$ or vocational $(9 \%)$. The questionnaire consisted of nine, often multiple closed questions. In some of them, the Likert scale was used; others were based on the semantic differential scale, still others involved a simple choice of statements describing the attitudes - respondents were also allowed to state other comments, some of which are used and cited in our paper. The questionnaire also included questions regarding the evaluation of the square's state before revitalisation.

The chapter also presents materials from two in-depth interviews. The first respondent is a member of the City Council, who was engaged in the revitalisation process. The second is a current member of the Community Council. However, during the revitalisation of the square, he was the only one involved informally as a member of a local movement. The aim of both sociological studies was to recognise the declarative attitudes held by the local community two years after the conflict around the square. Someone may ask why we waited with social research two years after the changes. We wanted to avoid in this way, during the survey research and in inhabitants' answers, the echo of social protests.

\section{A short story of one place - an empirical study}

\section{Description of the study area}

The "one square" and "one local community" which appear in the title may be defined as "the community around Asnyk Square" (Fig. 1 and Fig. 2). Asnyk Square covers the area of 2,256 $\mathrm{m}^{2}$ and is situated among the old buildings

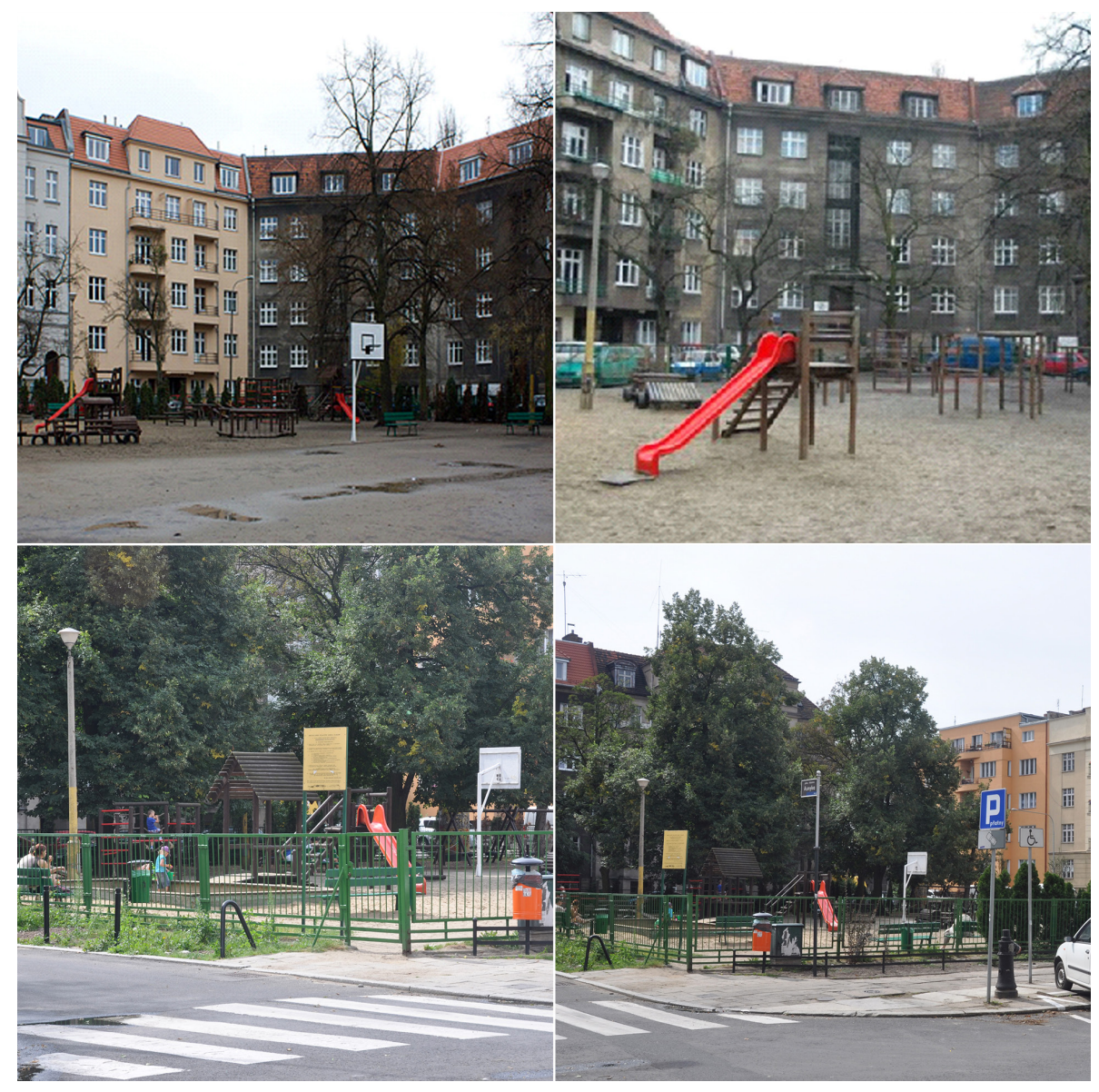

Fig. 1. Asnyk Square before renovation. Source: own compilation. 


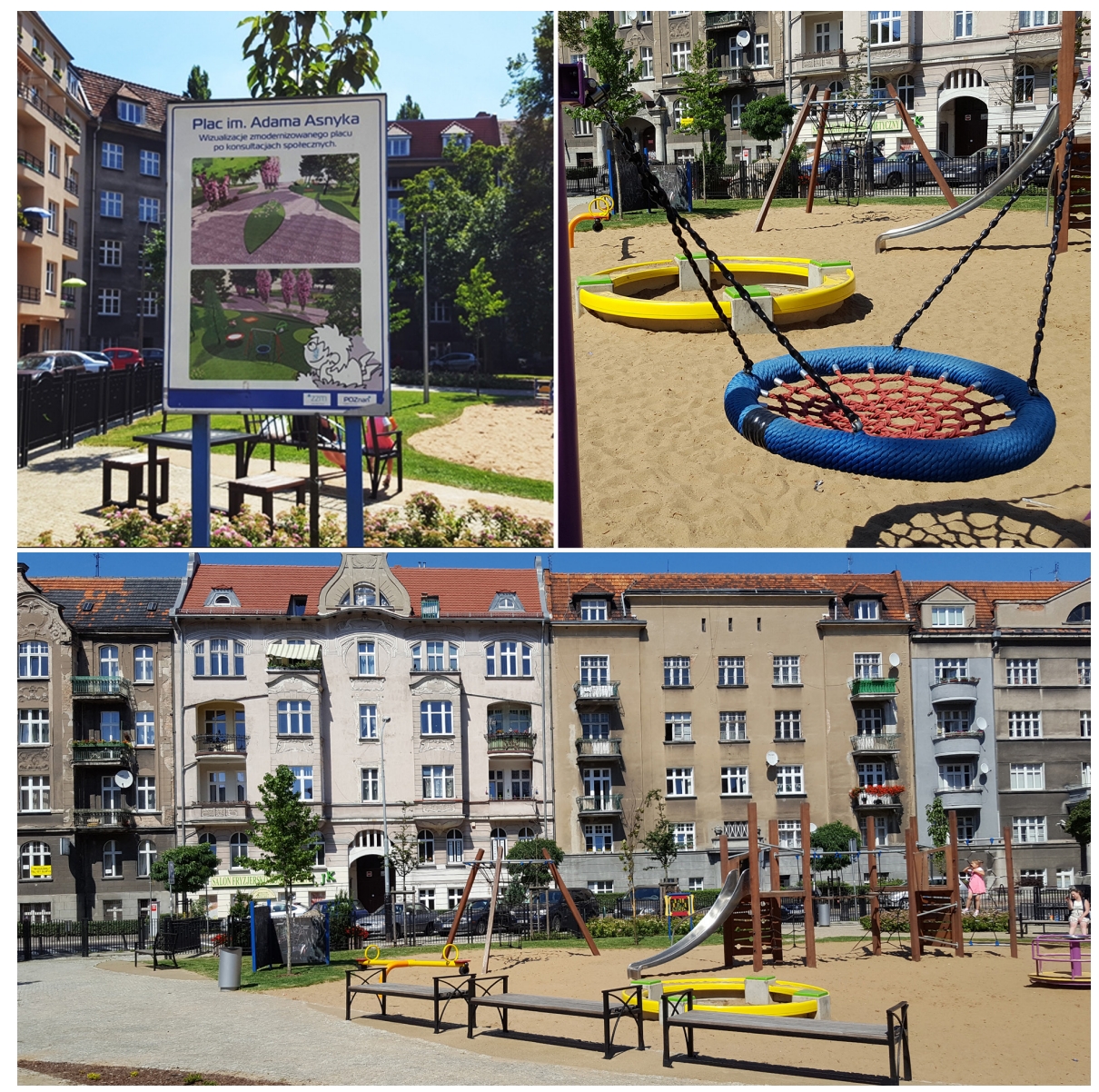

Fig. 2. Asnyk Square after renovation. Source: own compilation.

of the Poznan city centre (the map of the area: http://spatial-behavior.pl/maps/asnyka.html). Originally, it was a private garden belonging to the bourgeois Kosicki family, which they gave to the city in 1930. The benefactors made it clear that the area must never be built up and was to serve as a public space available to the inhabitants. Their condition was significant, considering that currently this area is the only open square furnished with benches and playground facilities within the area of several neighbourhoods. It is surrounded by old, compact tenement houses. Thus, it is a deliberately designed meeting place for the members of the local community.

During the interwar period, a part of the square was a football ground, which belonged to St. Kazimierz Private Elementary School - an exclusive educational institution attended by children from intelligentsia families. After the Second World War, Asnyk Square was a place where the inhabitants liked to meet and rest. It included a sandpit and a modest playground. In winter, an additional attraction for children and teenagers was a provisional ice rink, arranged on the fire water reservoir, dug by the city authorities. Paradoxically, such places flourished in socialist times. The city and the party authorities were in fact one body, so it was very easy to take a decision to renovate recreational facilities for the "working class". The fence, benches, playground and football ground equipment were renovated and repainted once a year. It is easy to guess that the symbolical date set for these activities was 1st May - the key holiday in a socialist state.

\section{The anatomy of place-making in the context of social communication}

Full of tall and low-growing greenery, Asnyk Square functioned as a place where people met to rest, talk and play until 2012. Despite the fact that most of its facilities were dedicated to children (sandpits, the playground and basketball court), the inhabitants of the nearby houses 
took advantage of it regardless of age or gender. Although the aesthetics of some elements of the area development caused some controversies, the place itself remained socially liveable. It enabled the local inhabitants to meet and they actually visited the place very willingly, which was confirmed by one of them:

"There, where the old square used to be, a fantastic picnic was organised. Half a year before that famous revitalisation. People came, it was like a breakfast market. This became popular in Poznań later, at different places. Totally spontaneous."

While in the socialist times the square was regularly renovated, mainly for propaganda purposes, after 1989, when the market economy was introduced, the decisions concerning the renovation of Asnyk Square were not related to propaganda any more. It was the money that started to count; the decisions depended on whether the city authorities had sufficient financial resources and whether there were other priorities regarding the spatial development of the city. The square continued to be the centre of local life, but it was slowly degrading.

\section{Local authorities take a decision - Attitude I: "We know better"}

We are singling out the year 2012 for a reason. It was when the local authorities took the decision concerning the revitalisation of the square and presented a provisional plan. However, it stayed on the shelf for nearly a year at the City Hall and nothing was being done. A year later, one of the local councillors, who was at the same time a neighbourhood inhabitant, submitted a project to the Poznań civic budget, proposing to restore the Art Nouveau character of Asnyk Square and transform it into the "Jeżyce salon" (Jeżyce - a Poznan district). The idea was not sufficiently supported by the inhabitants of Poznan and the project did not receive subsidies. In this situation, its author decided to apply for an urban grant for community councils. Eventually, one quarter of the needed resources was obtained, $50 \%$ of which were provided from the city budget and 50\% from the community council budget.

The project included: dismantling the existing elements of infrastructure (playground), hardening the surface by paving it with granite setts, reducing and refurnishing the part for children, installing an outside gym for adults, planting greenery, installing a fence and small architecture elements, benches, etc. The body responsible for those tasks was the Urban Green Administration Office (Zarzad Zieleni Miejskiej) in Poznań. Considering what happened later, it is important that the seats were to be made of concrete, and the playground zone surface - of polyurethane. The area intended for greenery was very limited; actually, the whole central part of the square was to be paved with setts (77\% of the area included in the project). Such plans meant changing the square - assumedly a meeting place - into a paved area without any greenery.

After finishing the design work, the city started to put it into practice. By the end of 2013, they had managed to dismantle the existing elements, pave the square and lay the foundations for the concrete seats. Also, the equipment for the new playground and the outside gym had been purchased. In the second year, the local community said: "Stop!" Having seen what was being done to the square, the inhabitants realised what the end-result will be.

\section{The inhabitants begin to act - Attitude II: "Let's talk in Social Media"}

The late and sudden awakening of the neighbourhood community resulted from the fact that it was excluded from decision-taking at the stage of designing the revitalisation project. Revitalisation works surprised the inhabitants - they criticised them and organised a protest in December 2013. The aim of the protesters was to withhold the works and introduce changes to the project. They placed slogans on the fence, expressing their refusal to accept revitalisation according to the authorities' vision. The inhabitants organised themselves very quickly, with the help of the Internet and social media. In January 2014, they organised a protest in the square, in the form of a happening, during which the inhabitants' postulates were read out and a symbolical picnic was organised. On that day, the inhabitants erected the statue of a paving stone into the square's space - a sarcastic comment on a product which, in their opinion, changed the square into "a salon of the dead". Such a paraphrase of the "Jeżyce salon" slogan promoted by the officials referred to the plans to harden the square surface and place boards 
commemorating meritorious neighbourhood inhabitants. The monument, which was put in the square for one day, was a symbolical expression of the objection to paving most of the square. As part of the protest, the inhabitants wrote a petition, soon signed by nearly 500 people living near the square. For the purposes of $a d$ hoc coordination and in order to keep posted about what is being done, the inhabitants created a dedicated profile on Facebook: "Asnyk Square for people. Movement against the salon of the dead". The profile quickly attracted other people and the number of "likes" approached one thousand. Its significance for the whole movement for introducing changes to the project was stressed by one of the in-depth study participants, who admitted that:

"More was happening on Facebook than physically, in the area $(. . .)^{\prime \prime}$.

The postulates of the indignant inhabitants, articulated during the protests, in traditional media and in social media, encompassed the following:

- removal of the paving setts,

- enlarging the playground and adding a sandpit as well as toys helping children to integrate,

- getting rid of the fence and replacing it with a low hedge,

- sowing a lawn,

- providing entertainment for users representing different age groups,

- placing chess and ping-pong tables in the square,

- setting up a small football ground.

\section{Without communication between formal Community Council representatives and the local community - Attitude III: "We represent neighbours"}

The urban institution which, by principle, is a link between the inhabitants and the city authorities is the Community Council. Its members should have looked after the interests of the neighbourhood inhabitants when the Poznan authorities started to execute a project which had such a strong influence on the local community's life. The community council is chosen in elections. In the case presented herein, it did not acquit well of its duties and did not meet the community's expectations. To make matters worse, a representative of the Council felt entitled to speak on behalf of the whole community and "consulted" the project with representatives of the city institutions on her own. She continued to behave this way even after she had been formally deprived of the right to represent the Council's standpoint. It is worth adding that it was the same person that had submitted the project to the civic budget earlier, who came up with ideas for introducing changes in the square. In this situation, the inhabitants addressed their reproaches and objections directly to the Community Council.

One of the inhabitants said:

"The Council mentioned consultations, but it seemed just like chatting to friends from the neighbourhood".

All the city authorities did was informing the inhabitants about top-down decisions.

Another inhabitant said:

"Information boards appeared, saying what was being built there. Here, they were put mainly on the corner - the investor's boards. They were to convince people. Such a beautiful visualisation. Most things were simply in green. This is rather one-directional information".

Problems with the flow of information between city institutions were also signalled by one of the alderwomen, who was a member of the grant commission:

"As a commission, we did not understand from the proposal at all that somebody wants to pave this green, grassy area. We assumed that it would be as it was - a green playground, and that someone wants to install some new toys there. Just buy and place them there. There was one large sandpit and we didn't even think of getting rid of it. All of a sudden, setts appeared all over the square. A whole lot of these setts, an awful lot! And the commotion started."

During the same interview, the Community Council representative clearly stressed the conflict of interest between the community and the authors of the project (at the time - members of the Community Council), which concerned turning Asnyk Square into the "Jeżyce salon": 
"The expectations of these two ladies who started the campaign (Community Council members the authors' comment) were completely different from the expectations of the inhabitants who actually used this square and went there with children. They wanted the place to be kids-friendly - a lot of sand, a lot of grass. And the two ladies wanted a beautiful place for adults".

\section{An attempt to relieve the tensions - Attitude IV: "It's easy to be wise after the event"}

After the first protest, the Director of the Urban Green Administration Office assured the inhabitants that they would be allowed to submit their comments regarding the project and he planned public consultations. We should stress the fact that they were planned after the construction works had begun. As a result, it was too late to introduce radical changes to the project, and the situation was made even more difficult by officials, who refused to allocate additional means to revitalise the square. Ignored at the designing stage, the inhabitants were afraid of pretentious consultations, which would not offer any possibilities of real change.

The moves were not satisfactory for the inhabitants. Their remarks were still not taken into account, and the provisions of the tender clearly stated that the revitalisation of the square will follow the original plan.

The subsequent protest in the middle of 2014 resulted in the intervention of the Poznan vice-president. The Director of the Urban Green Administration Office was excluded from the works, and the project became subject to the next round of consultations. Also in this case, community workers had many reservations, especially regarding the dates of meetings. When the representatives of the city authorities informed they would be absent, the meetings were postponed, but if a representative of the inhabitants could not come - the meeting was held anyway. Here is what one of the inhabitants told us during an in-depth interview about the attendance at the consultation meetings:

"And then the meetings started. Several. In the school in Jeżyce, one or two, and at least two in the City Hall. There were more or less 10 of us. Sometimes 500 people signed but only 10 came. But that's how it is with most things, because it's rather impossible to attract more people to this sort of things".

A partial compromise was commented by one of the alderwomen in the following words:

"And later, negotiations followed. One community councillor, then another one - everybody quarrelled with everybody else, asked who could have approved of such a plan. Finally, they came to a kind of a compromise - the investor agreed to take off some of the setts, but not too many. They also agreed to put in some more playground equipment; earlier, it was to be symbolic. First they said there would be no sandpit. What for? The kids will take the sand home. But finally, they agreed to put in the sandpit as well".

\section{A short summary of place-making in the context of communication}

The anatomy of communication schemes around the renovation of Asnyk Square in Poznań enabled us to identify the social attitudes of several entities. We named these attitudes, using the behavioural model of participation developed by Kotus and Sowada (2017) and extending Arnstein's ladder (1969). Arnstein finished her ladder of participation on the citizen power. Nevertheless Kotus and Sowada asked what happened when citizens weren't able to move from the tokenism stage to citizen power. To answer this question, the authors added another four levels of social action to the behavioural model of participation: awakening, civil disobedience, radicalisation, rebellion. All of these "new" ways of participation, according to Kotus and Sowada, are characteristic of societies and communities which are blocked in their citizens' rights.

Here are the attitudes we identified in our desk and field research:

\section{Attitude I "We know better" - city authorities' tokenism}

This attitude is related to the decision concerning the revitalisation of the square, taken by the local authorities. Regrettably, it was just a decision (without any follow-up action) and it was 
not consulted with the inhabitants. Given lack of action on the part of the local authorities, this decision overlapped with the opinions of some members of the Community Council. They decided to take matters into their own hands and started to apply for financing the revitalisation from the city competition funds. Those are special low-budget grants for the local communities of Poznan to implement interesting urban planning ideas. In this particular case, the Community Council started to act, but again without consultations with the inhabitants. Somewhat secretly, the plan to create the "elegant Jeżyce salon" started to come into life. The authors of the project, who were at the same time members of the Community Council, started to implement their ideas. We may close this stage with a comment regarding the attitudes presented by the city authorities and the members of the Community Council: public means nobody's, so perhaps mine, almost private.

\section{Attitude II "Let's talk in Social Media" - the awakening of the local community}

The city authorities took it at face value that someone wants to deal with the "problem" instead of them. They allocated minimum grant means and believed that it would work out somehow. The project started to be put into life. First, benches and structures for children were removed from the square. It is easy to guess that the NIMBY mechanism appeared right away. When the inhabitants saw what was happening, they awakened, communicated and started to integrate and protest. In this case, naming the attitude may be translated as "let us do something, because somebody is changing our small world for us and without us." However, we can add "without communicating with us".

\section{Attitude III “We represent neighbours" - civil disobedience against tokenism}

It turned out that the inhabitants wanted something different than their representatives. Formal representatives chosen by the neighbourhood community quickly realised that they had the power in their hands. That resulted in natural and inevitable, in our opinion, attitudes involving abuse of power due to having access to information which is not available to everybody. In this situation, the inhabitants protested and the
Community Council members (also neighbourhood residents, but at the same time the authors of the project) consulted the project (rejected by the inhabitants) with the city authorities, and the construction works commenced. We suggest naming the situation in a descriptive way as civil disobedience, i.e. demonstrating the lack of communication between formal representatives of local communities and inhabitants.

\section{Attitude IV "It's easy to be wise after the event" - the local authorities' collaboration}

The conflict developed and attracted the local media. As the social attitudes and growing protests became more radical, the city authorities listened to the inhabitants and withheld the reconstruction of the square. Next, the project was modified, according to the inhabitants' suggestions. The Community Council was excluded from the discussion, and in the next elections, the inhabitants chose many new members, including some leaders of the protest. It was one of the indirect effects of the battle for the square. The Community Council was significantly changed. We may say that the actual cooperation was forced by social protests, in other words: a form of open communication against... the city authorities gave the floor to the inhabitants once they had had a say themselves.

Two years after the conflict finished, we decided to conduct sociological research. It was to show how strongly the attitudes from 2013-2015 became rooted among the inhabitants of this area and whether the people were satisfied with the square and used it. Even the initial analyses of the situation encouraged us to conduct further studies. Here is what one of the inhabitants said:

"The conflict was in a way useful, as it stopped the original plan for a paved square with concrete benches, without any recreational facilities. But the final effect is not satisfactory and it wasn't the best way of spending 162,262 euros".

Members of the new Community Council are still engaged in discussions with the city authorities about introducing other changes in the square. However, given the difficulties in gaining financial means, only cosmetic changes could be made, such as installing football and pingpong tables. What, then, do the inhabitants of the 
surrounding houses currently think about their participation in place-making, the functionality of the square and the actors involved in the conflict a few years ago?

\section{Declarative attitudes - inhabitants' opinions after some time}

The results obtained will be presented with respect to the following: the opinions, views and expectations of the inhabitants, regarding social participation and their influence on the immediate environment; information concerning Asnyk Square in the life of the local community; opinions and views regarding the revitalisation of the square. The analysis of the results was supported by the inhabitants' statements given during indepth talks and by the movement leader (presently a Community Councillor) and a Poznań alderwoman during in-depth interviews.

\section{Inhabitants' expectations as regards social participation and their influence on the immediate environment}

The introductory questions in the survey concerned the inhabitants' general attitudes towards participation in matters connected with spatial development and the forms of this participation. First, we asked the inhabitants if they thought they had any influence on spatial development, on a few local scales: in their own house and backyard, their housing estate and the city district. The majority of respondents believe that they do not have any influence on the matters connected with their own house and its closest vicinity (Fig. $3^{1}$ ). A fairly small number think that they do have some influence in this respect. We also asked a similar question whether the inhabitants would like to have an influence on the matters connected with their environment. The results show how far the inhabitants' expectations differ from how they evaluate the current situation. At each spatial level, most inhabitants would like to have more to say about how the urban space is developed. The larger the spatial range involved, the fewer affirmative answers

The net 'yes' index was calculated by subtracting the sum of 'nos' (definitely not, rather not) from the sum of 'yeses' (definitely yes, rather yes). It assumes a value from - 100 (highly negative) to 100 (highly positive).

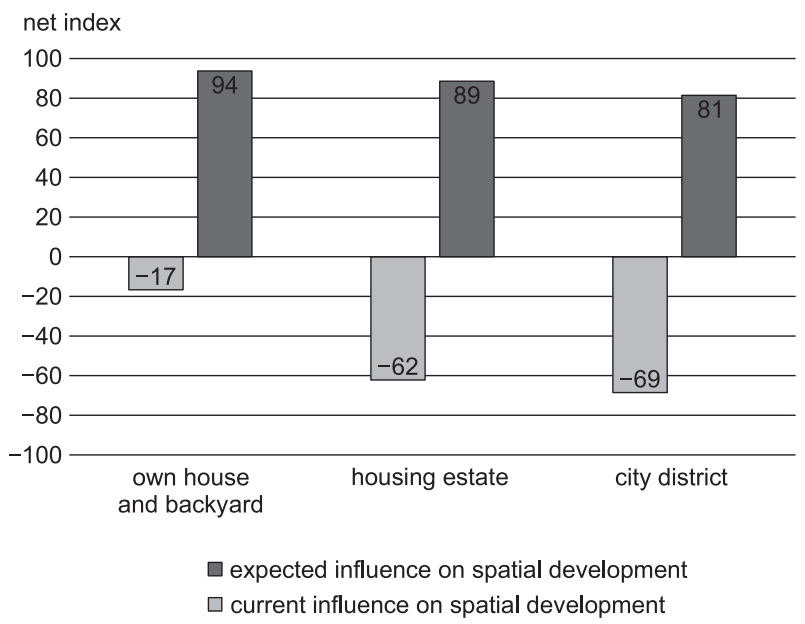

Fig. 3. Inhabitants' opinions regarding their current and expected influence on spatial development - net index.

Source: own compilation.

were given, with respect to both - the current situation and the future expectations. The inhabitants are most interested in having an influence on their own surroundings (own backyard), and definitely less as regards the influence on the development of the housing estate and the whole city district. This linear differentiation is caused by various spatial or/and psychological and social factors, also those resulting from the current social order (Hidalgo, Hernandez 2001; Lewicka 2010). In our article, these factors and their origins are not as crucial as the statement that, firstly, interest and involvement in the problems of the neighbourhood are two different things and, secondly, the declared interest is smaller than that which is potentially expected. In other words, at least those inhabitants who are kept informed about the matters of their neighbourhood would like to be more involved than they presently are, their present involvement being largely declarative.

The respondents suggested indicating a place where those who want to get involved could report problems and suggest ideas. The matters discussed above, concerning the inhabitants' social participation and influence on the environment, let us conclude that the respondents are interested in the problems of their neighbourhood, they would like to have a larger influence on it than they do now, and they are more open to various forms of contact with the city authorities. 
The role of Asnyk Square in the life of the neighbourhood in the respondents' opinion, two years after changes

The next set of questions preceding the questions directly connected with the revitalisation of Asnyk Square referred to the evaluation of its role in the life of the local community. In this part of the study, we asked the inhabitants how often they visited and how they used the square. Nearly one fourth of the respondents do not visit it at all (Fig. 4). They claimed that after rebuilding, the square had become more mentally distant to them: "It was as if somebody had changed something without asking us for an opinion". On the other hand, there are a small number of

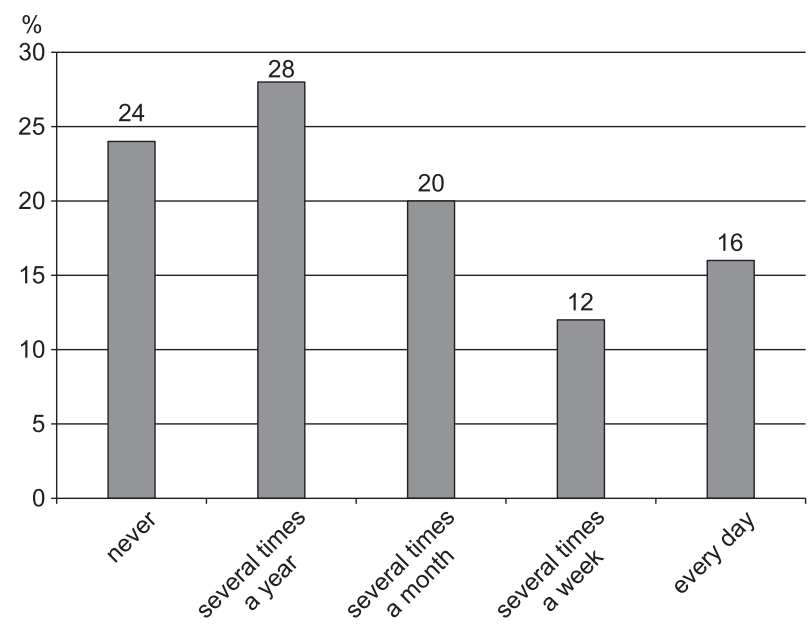

Fig. 4. The frequency of the respondents' visits at Asnyk Square (\%).

Source: own compilation. people who visit it every day. Most inhabitants appear at the square occasionally, on average several times a year.

We also asked the inhabitants of the nearby houses in what way they used the square. Some of them just rest there. A fairly large number come to the square to meet other people and talk to them. This social aspect of staying in the square can be seen in people's participation in physical activities and games (Fig. 5). Many users also read books and magazines. Activities such as walking the dog, drinking alcohol, cultural events and exercising were indicated by one or two people. Let us add that both, walking the dogs and drinking alcohol in the square is illegal. These two activities were suggested by the respondents. The liveable character of the place is also proved by the inhabitants' statements in in-depth interviews:

"There, around this small sandpit, about 50 people get together. I have taken photos - sometimes even $30-40$ kids. They are hanging on one rope together. It's terribly popular".

The questionnaire survey shows that the square has a very cosy atmosphere, at least for the inhabitants included in the study. It is a relatively frequently visited place, where people of different age meet, rest and play. By staying there, the inhabitants of the nearby houses rest and have a chance to talk with someone, and a place where children can play. The results clearly show that it

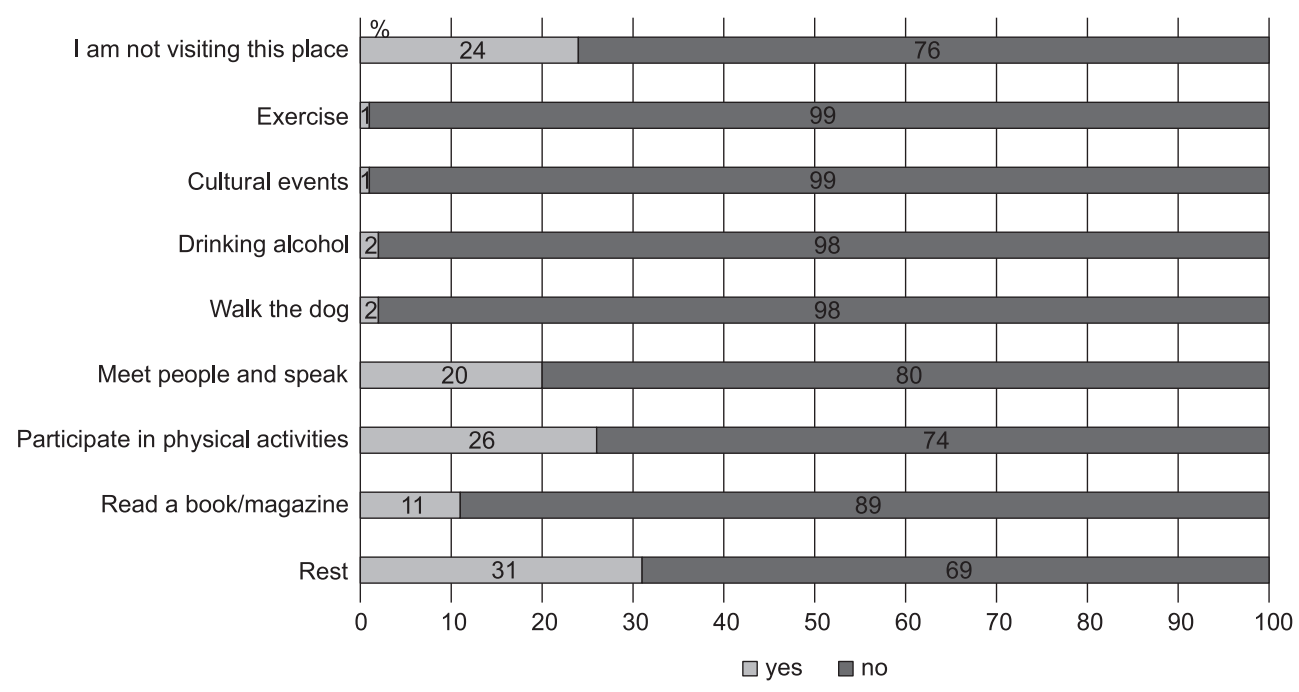

Fig. 5. The ways in which the respondents use Asnyk Square (\%). Source: own compilation. 
is a place which integrates families, as it is visited by couples, parents with kids, as well as grandparents with grandchildren. Thus, it can be said that despite the complaints of the present members of the Community Council about the final result of the reconstruction, the place is vital for the inhabitants, who "stigmatise it by using it".

\section{The respondents' opinions about the stakeholders of the place-making process}

The members of the local community included in our study assessed which actors involved in space development could be trusted. Those who were rated higher included the inhabitants, the Community Council, as well as local associations and urban movements (Fig. 6). A visible percentage of negative opinions were given about the City Council and the Urban Green Administration Office. It may be surprising that the Community Council was rated so high, considering that formerly this particular institution had often been blamed for secretive dealings, against the inhabitants' will. It can be explained by the fact that the study was carried out after the revitalisation and, what is more important, after elections, won by the people who had earlier taken part in protests in the square. We should remember that the inhabitants' accusations concerned individual councillors, who had acted behind their backs and without any authorisation to represent the Council. At this point, it is worth mentioning the opinion of one of the councillors, expressed during an in-depth interview:

"Well, the community council is such a heterogeneous body. We also have different opinions in our Council, and that former council, as far as we could see, was even more divided - so much, that at the end of their term of office they couldn't even gather eleven people".

The other dimension, in which the revitalisation actors engaged in the changes at the square were assessed, was the question of caring for common good. Again, positive opinions were expressed more often with respect to the Community Council, inhabitants, as well as local associations and urban movements (Fig. 7). Definitely, the
Urban Green Administration Office was rated the lowest; it was described as uncaring for the common good clearly more often than the City Council. The study identified categories of social actors estimated generally positively or generally negatively. The former included: (1) the inhabitants who in response to the realisation of the project which had not been consulted with them or did not satisfy their needs decided to protest; (2) local associations and urban movements, which supported the protest organisationally by facilitating grassroots activity; (3) the Community Council, which supported the local inhabitants at a certain stage of the process. Negative opinions concerned: (1) the Urban Green Administration Office which, as a consequence of its actions, unaccepted by the inhabitants, was finally excluded from the project; (2) the City Council, which was insufficiently engaged in solving the conflict.

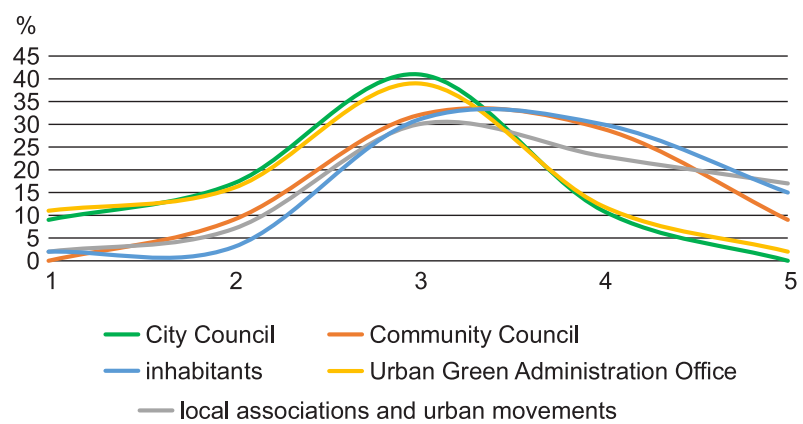

Fig. 6. The evaluation of the square renovation actors, ranging from 'could not be trusted to 'could be trusted' (number of answer). Source: own compilation.

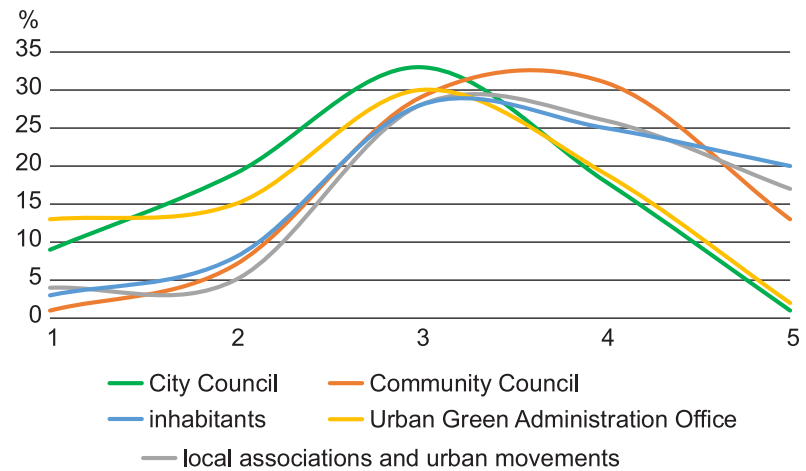

Fig. 7. The evaluation of the square renovation actors, ranging from 'not caring about common good' to 'caring about common good' (number of answer). Source: own compilation. 


\section{A short summary of the declarative attitudes after some time}

To distinguish certain characteristic attitudes based on inhabitants' declarations, we may point to the following:

- declared interest in having an influence on the surroundings and the lack of real influence;

- satisfaction with the present state and functions of the square inferred from the declaration that it is regularly used;

- a clear division, at least at the present moment, into two categories of beneficiaries, who the respondents believe are trustworthy and caring for the common good. One includes the inhabitants, social movements and the Community Council, while the other - the city hall institutions, on the other end of scale.

It is easy to observe a polarisation of attitudes in the Us - Them dimension, where They are the city authorities and the City Hall officials. Let's stress once again that the present Community Council includes many members of the same social movement which protested against the original project in 2013-2015.

\section{Discussion and conclusions}

We have presented the social attitudes and the communication process connected with the revitalisation of a square in a large Polish city. Due to the relatively long observation of the social phenomena accompanying the revitalisation of the square, we were able to recognise not only the communication mechanisms manifested through actual actions during the place-making process, but also those which were declared by the community two years after the construction works were completed. This allows us to accomplish our goal, which was to establish the anatomy of place-making in the context of social communication and social order.

We can formulate the following conclusions:

- During the place-making process, the inhabitants displayed a very passive attitude that changed drastically when the future image of the square became known. The range and dynamics of this change were strengthened, firstly, by the lack of any talks between representatives of the local authorities and the inhabitants at the initial stage of transforming Asnyk Square; secondly, by the decision-taking wilfulness on the part of the representatives of the Community Council, who took decisions favourable for them on behalf of the local community; and thirdly, by some kind of the inhabitants' "sleep mode" in relation to the neighbourhood. It may also be the case of almost allergic reaction to breach of newly acquired trust that is scarce in the context of Central and Eastern Europe (Rose-Ackerman 2001).

- The inhabitants did not expect revolutionary changes during the place-making process. They only wanted Asnyk Square to keep up its function of a liveable place, where they can spend time with children, and the children have a place to play. We can even propose a thesis that the inhabitants did not expect any changes, but they only wanted to maintain the status quo of the square in its social usefulness. Those expectation may be also attributed to the perceived, very limited role of the Community Council in shaping public space.

- The city authorities remained passive for a very long time during the place-making process, silently delegating the responsibility for organising it to the Community Council.

- The representatives of the Community Council, on the other hand, took advantage of the whole situation to change the function of the square in the course of place-making. It was to lose the character of a playground and turn into the "Jeżyce salon". It was an attempt to satisfy the wishes of some people who were the inhabitants' representatives in the Community Council.

- Two years after the conflict around the development of the square, the inhabitants included in the study still mistrust the city authorities and the City Hall officials.

- The square itself is popular with the respondents, who willingly use this place.

The question remains whether it was possible to start from talks with the inhabitants at the stage when the decision concerning the revitalisation of the square was taken, in 2012. The answer is obviously simple - it was absolutely possible to do that. Here, however, the special character of the social order interfered - the specificity of a post-socialist city: 
- lack of established schemata of talks between local authorities and inhabitants, perhaps lack of communication mechanisms in general,

- arbitrary behaviour of the Community Council members and its lack of perceived accountability, which is to be expected in a low-trust environment (King et al. 1998) as well as the lack of communication between them and local residents,

- lack of everyday information for the inhabitants about the plans concerning their place of residence,

- the inhabitants' passivity until action is taken by the local authorities.

In the post-socialist reality, the authority (even at the local level) is very often "an authority over someone". On the one hand, instead of cooperating with the inhabitants, the authorities rule them, while on the other, they are perceived by the citizens as the elite, distancing themselves from the community. This heritage of many decades is very difficult to root out from the social mentality.

In our particular case, the city authorities were not aware of the necessity to negotiate with the inhabitants (of just one neighbourhood, consisting of several hundred people), based on the assumption that the Community Council represents the inhabitants and there are no reasons for a different form of discussion than that with the Council. The Council, in turn, since it represented the community, decided that everything was allowed and could be done regardless of the inhabitants' opinions - they do not felt accountable. The whole situation stemmed from certain communication schema and rituals resulting from the socio-cultural order of this particular community, city and region of Europe.

These particular attitudes may then lead to a more violent response, which we call the "awakening" of the local community to mutual communication (also via social media) and action. It is action which they have never taken before and which has not been in their character so far. The specificity of the social order may also consist in the distancing of the local community representatives (formal community councils) from the inhabitants and the local authorities (chosen in elections!) and the reluctance to talk to the inhabitants. In our opinion all the individual attitudes described above may come down to one thing determining the effectiveness of place-making - "the ability or inability to communicate". Perhaps place-making means more than planning and rebuilding squares, backyards, walking streets and waterfronts. Perhaps place-making is closer to communication-making than city planners (in that context in Poland) think and place-making without clear communication is rather a place-breaking process.

\section{Acknowledgement}

This work was supported by the National Science Centre, Poland; grant number UMO 2014/15/B/HS4/00839.

\section{References}

Adams P.C., 2005. The boundless self. Communication in physical and virtual spaces. Syracuse University Press, Syracuse.

Adams P.C., 2009. Geographies of media and communication: A critical introduction. Wiley-Blackwell, Oxford.

Adams P.C., 2017. Geographies of media and communication I: Metaphysics of encounter. Progress in Human Geography 41(3): 365-374.

Andrusz G., Harloe M., Szelenyi I. (eds), 1996. Cities after socialism: Urban and regional change and conflict in post-socialist societies. Wiley-Blackwell, Oxford.

Anguelovski I., 2013. From environmental trauma to safe haven: Place attachment and place remaking in three marginalized neighborhoods of Barcelona, Boston, and Havana. City and Community 12(3): 211-237.

Block P., 2009. Community: The structure of belonging. Berrett-Koehler Publishers, Oakland.

Clark J., Kearns A., Cleland C., 2016. Spatial scale, time and process in mega-events: The complexity of host community perspectives on neighbourhood change. Cities 53: 87-97.

Davies N., 1981. God's playground. A history of Poland. 1795 to the present. Vol. 2. Oxford University Press, Oxford.

Dear M., 1992. What kind of social communication accompany place-making processes from citizens point of view? Journal of the American Planning Association 58(3): 288-300.

Devine-Wright P., 2015. Renewable energy and the public: From NIMBY to participation. Routledge, New York, London.

Downs A., 1981. Neighborhood and Urban Development. Brookings Institution, Washington D.C.

Forrest R., 2000. Does neighbourhood still matter in a globalised world? Occasional Paper Series No. 5, Centre for Comparative Public Management and Social Policy. University of Hong Kong, Hong Kong City.

Friedmann J., 2010. Place and place-making in cities: A global perspective. Planning Theory \& Practice 11(2): 149-165.

Galster G., 2001. On the nature of neighbourhood. Urban Studies 38(12): 2111-2124.

Glikman A., Semyonov M., 2012. Ethnic origin and residential attainment of immigrants in European countries. City and Community 11(2): 198-219. 
Grant J., Mittelsteadt L., 2004. Types of gated communities. Environment and Planning B: Planning and Design 31(6): 913-930.

Gu Hongyan, 2016. NIMBYism in China: Issues and prospects of public participation in facility siting. Land Use Policy 52: 527-534.

Hanhörster H., Weck S., 2016. Cross-local ties to migrant neighborhoods: The resource transfers of out-migrating Turkish middle-class households. Cities 59: 193-199.

Hidalgo C.M., Hernández B., 2001. Place attachment: Conceptual and empirical questions. Journal of Environmental Psychology 21(3): 273-281.

Hirt S., Ferenčuhová S., Tuvikene T., 2016. Conceptual forum: The "post-socialist" city. Eurasian Geography and Economics 57(4-5): 497-520.

Jacobs J., 1992. The death and life of great American cities. Vintage Books, New York.

Jansson A., Falkheimer J. (eds), 2006. Geographies of communication. The spatial turn in media studies. Nordicom, Göteborg.

King C.S., Feltey K.M., Susel B.O., 1998. The question of participation: Toward authentic public participation in public administration. Public Administration Review 58(4): 317-326.

Kotus J., 2006. Changes in the spatial structure of a large Polish city - The case of Poznań. Cities 23(5): 364-381.

Koziołek K., 2013. Poznań: Plac Asnyka odzyska secesyjny charakter. http://Poznań.naszemiasto.pl/artykul/ Poznań-plac-asnyka-odzyska-secesyjny-charakter,1706881,art,t,id,tm.html (accessed: January 2013).

Larsen S.C., Johnson J.T., 2016. The agency of place: Toward a more-than-human geographical self. GeoHumanities 2(1): 149-166.

Lepofsky J., Fraser J., 2003. Building community citizens: Claiming the right to place-making in the city. Urban Studies 40(1): 127-142.

Lewicka M., 2010. What makes neighborhood different from home and city? Effects of place scale on place attachment. Journal of Environmental Psychology 30(1): 35-51.

Low S., 2004. Behind the gates. Life, security and the pursuit of happiness in Fortress America. Routledge, New York, London.

Martin D.G., 2003. "Place-framing" as place-making: Constituting a neighbourhood for organizing and activism. Annals of the Association of American Geographers 93(3): 730-750.

MazurN., 2014. Plac Asnyka-darod bambrów z Jeżyc. http:/ / Poznań.wyborcza.pl/Poznań/1,36001,15412260,Plac_ Asnyka_dar_od_bambrow_z_Jezyc.html (accessed: January 2018).
McClymont K., 2011. Revitalising the political: Development control and agonism in planning practice. Planning Theory $10(3)$ : $238-256$.

Middleton A., Murie A., Groves R., 2005. Social capital and neighbourhoods that work. Urban Studies 42(10): 17111738.

Miessen M., 2011. The nightmare of participation (crossbench praxis as a mode of criticality). Sternberg Press, Berlin.

Miller J.G., Das R., Chakravarthy S., 2011. Culture and the role of choice in agency. Journal of Personality and Social Psychology, 101(1), 46-61. https:// doi.org/10.1037/ a0023330

Moote M.A., McClaran M.P., Chickering D.K., 1997. Theory in practice: Applying participatory democracy theory to public land planning. Environmental Management, 21, 6: 877-889.

Oakes T.S., Price P.L., 2008. The Cultural Geography Reader. London and New York: Taylor \& Francis.

Owens A., 2012. Neighborhoods on the rise: A typology of neighborhoods experiencing socioeconomic ascent. City and Community 11, 4: 345-369.

Patterson M., 2016. The global city versus the city of neighborhoods: Spatial practice, cognitive maps, and the aesthetics of urban conflict. City and Community 15, 2: 163183.

Pløger J., 2004. Strife: Urban planning and agonism. Planning Theory 3, 1: 71-92.

Reed M.S., 2008. Stakeholder participation for environmental management: A literature review. Biological Conservation 141(10): 2417-2431.

Rose-Ackerman S., 2001. Trust and honesty in post-socialist societies. Kyklos, 54, 2-3: 415-443.

Saint M.P., Flavell R.J., Fox P.F., 2009. NIMBY wars. The politics of land use. Philadelphia: Saint University.

Schirato T., Yell S., 2000. Communication and culture: An introduction. Sage Publications

Sevilla-Buitrago A., 2013. Debating contemporary urban conflicts: A survey of selected scholars. Cities 31: 454-468.

Sprawozdanie z audytu 2014. Audyt inwestycji pn. Rewitalizacja Placu Adama Asnyka. https://www.facebook. com/placdlaludzi/ enter November 2014

Tsenkova S., Nedović-Budić Z., 2006. The urban mosaic of post-socialist Europe. Contributions to Economics Series: Springer.

Walljasper J., 2007. The great neighbourhood book. A do-it-yourself guide to placemaking. Gabriola Island: New Society Publishers.

Wiliams J.J., 2000. South Africa: Urban transformation. Cities 17(3): 167-183.

Wu Z., Hou F., Schimmele C.M., 2011. Racial diversity and sense of belonging in urban neighborhoods. City $\mathcal{E}$ Community 10(4): 373-392. 